\title{
Krynicki, labirynt, zagadka
}

Aleksander Wójtowicz

TEKSTY DRUGIE 2018, NR 6, S. 154-160

DOI: $10.18318 /$ td.2018.6.12

$\mathbf{K}^{5}$

siążka Iwony Misiak poświadcza niesłabnące zainteresowanie twórczością Ryszarda Krynickiego. W ciągu kilkunastu lat ukazały się prace, które w znaczący sposób pogłębiły dotychczasową wiedzę na temat dorobku autora Aktu urodzenia, odsłaniając i gruntownie opisując jego związki z XX-wiecznymi programami artystycznymi, estetykami, ideologiami. I choć wciąż jeszcze nie powstała monografia, która podjęłaby próbę całościowego opisania tego dynamicznego, a jednocześnie bardzo zawiłego projektu pisarskiego, to znaczna część jego aspektów została omówiona w książkach Aliny Świeściak², Tomasza Cieślaka-Sokołowskiego ${ }^{3}$,

1 I. Misiak Poczq̨tek zagadki. O labiryntowej twórczości Ryszarda Krynickiego, Stowarzyszenie Pro Cultura Litteraria - Wydawnictwo IBL PAN, Warszawa 2015.

2 A. Świeściak Przemiany poetyki Ryszarda Krynickiego, Universitas, Kraków 2004.

3 T. Cieślak-Sokołowski Moment lingwistyczny. O wczesnym pisarstwie Ryszarda Krynickiego iStanisława Barańczaka, Universitas, Kraków 2011.

\section{Aleksander \\ Wójtowicz - dr hab., adiunkt w Zakładzie Literatury Współ- czesnej Instytutu Filologii Polskiej UMCS w Lublinie. Autor książek Cogito

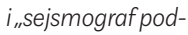 świadomości."Proza Pierwszej Awangardy (2010), Nowa Sztuka (początki i końce) (2017). Publikował m.in. ${ }_{\text {„Pamiętniku }}$ Literackim”, „Ruchu Literackim”, „Przeglą- dzie Humanistycz- nym”, ,Kwartalniku Filmowym". Kontakt: aleksander.wojto- wicz@poczta.umcs. lublin.pl.}


jak również szkicach opublikowanych w tomach zbiorowych4 ${ }^{4}$. Badaczom udało się zidentyfikować najważniejsze - przywołajmy określenie Mariana Stali - „drogowskazy, jakie Ryszard Krynicki rozmieścił na granicach swego poetyckiego świata"s. A również wytyczyć obręb jego granic, skatalogować tereny doń przylegające oraz zrekonstruować genezę, będącą wypadkową wielu dyskursów, jakie kształtowały rozwój liryki ostatnich kilkudziesięciu lat. Mimo to pytania, jak ów świat powstał oraz jakim przemianom podlegał, są wciąż dalekie od rozstrzygnięcia, tym bardziej że wciąż pojawiają się nowe pomysły interpretacyjne, które uzupełniają, a jednocześnie komplikują wiedzę na temat twórczości Krynickiego.

Początek zagadki jest taką propozycją z paru względów. Przede wszystkim dlatego, że zawiera interesującą próbę odczytania poezji Krynickiego na podstawie kontekstów, jakie do tej pory nie zawsze znajdowały się w centrum uwagi historyków literatury. Inspiracją dla Iwony Misiak stały się bowiem dzieła myślicieli antycznych, a przede wszystkim - Heraklita z Efezu i Parmenidesa zElei, a w szerszym wymiarze - ,klimat epoki preplatońskich mędrców, kiedy formowały się filozofia i poezja" (s. 9). Od pierwszego myśliciela Misiak zapożycza pojęcie logosu, który „istnieje transcendentnie i immanentnie” $i$,jest rozumnym ogniem, którego reguły wyznaczają przemiany widzialnego świata" (s. 9), od drugiego - kategorię prawdy bytu, który "pozostaje nieruchomy i niezmienny"6 (s. 10). Bieguny te wytyczyły ramy poszukiwań filozofów przedplatońskich, którzy w swoich rozważaniach poszukiwali archai, a równocześnie usiłowali odnaleźć odpowiedź na pytania o istotę natury i praw nią rządzących?.

Umieszczona w takim horyzoncie poezja staje się poszukiwaniem prawdy. Jest to jednak zadanie uwikłane w szereg kłopotów i sprzeczności, bo przecież skoro koncepcje wspomnianych myślicieli w sposób pośredni wskazują na fakt, że każda „próba wyrażenia świata odsyła do sfery zjawisk ukrytych

4 Słowa? Tchnienia? O poezji Ryszarda Krynickiego Wydawnictwo Wojewódzkiej Biblioteki Publicznej i Centrum Animacji Kultury, Poznań 2009 oraz Pismo chmur. Studia i szkice o poezji Ryszarda Krynickiego, red. P. Próchniak, EMG, Kraków 2014.

5 M. Stala Dziewięć ścieżek wprowadzających w świat Ryszarda Krynickiego, w: Pismo chmur..., s. 17.

6 W tym kontekście intrygująco prezentuje się przywołany przez Misiak kontekst neoparmenidejski, któremu patronują wywody Emanuele Severino zawarte w Powrocie do Parmenidesa (przeł. M. Sokołowski, Wydawnictwo IFiS PAN - Instytut Filozofii i Socjologii PAN, Warszawa 2005), a zwłaszcza koncepcja dwóch ścieżek: Prawdy i Nocy.

7 Por. .. Gajda-Krynicka Filozofia przedplatońska, PWN, Warszawa 2007 (zwłaszcza rozdział Filozofia przedplatońska jako poszukiwanie zasad - archai). 
za przedstawieniem" (s. 15), to sens bytu nieodmiennie ukazuje się w sposób niepełny. Wywody Misiak zostały oparte na intrygującym założeniu, że w twórczości Krynickiego pojawia się silne przeczucie istnienia owej „innej” rzeczywistości, objawiającej się w sposób zagadkowy i fragmentaryczny, a jednocześnie rozpatrywanej z perspektywy przywodzącej na myśl koncepcje filozofów epoki przedplatońskiej. Patronem zawartych w Początku zagadki rozważań na ten temat stał się Giorgio Colli, przede wszystkim zaś jego koncepcje wyłożone w Filozofii ekspresji oraz Narodzinach filozofii, dotyczące zarówno „ezoteryczności wszelkiego logosu” (s. 15), jak i sprzęgniętego z nim w nierozerwalny sposób mechanizmu ukrywania sensu, którego figurami są przypowieści, zagadki oraz konstrukcje o charakterze labiryntowym ${ }^{8}$. Analogiczna zasada organizuje dynamikę poszukiwań Krynickiego, w którego twórczości można dostrzec dwa wywodzące się z greckich rytuałów mechanizmy ukrywania tajemnicy: dionizyjski labirynt (analizowany w cz. I) oraz apollińską zagadkę (cz. II). Stawką przebrnięcia przez pierwszy oraz rozwikłania drugiej ma być pogłębiona wiedza o sensie istnienia.

Sformułowany na podstawie takich założeń projekt interpretacyjny jest niewątpliwie oryginalny. A poniekąd także prowokacyjny, ponieważ Misiak w swoich rozważaniach w zasadzie całkowicie pomija XX-wieczne koncepcje estetyczne, które narzucają się jako pierwsza, niejako naturalna matryca interpretacyjna twórczości Krynickiego, dzielącej wiele wątpliwości i rozterek z epoką, w której powstała. W Początku zagadki nie pojawiają się rozważania na temat artystycznych i etycznych dylematów awangardy, które w znaczny sposób przeniknęły do wierszy Nowej Fali, brak tutaj też odniesienia do licznych uwarunkowań kształtujących oblicze rodzimej liryki nowoczesnej. Wszystko to zostało odsunięte na dalszy plan, przesłonięte przez próbę opisania dialogu ze sprawami o wiele odleglejszymi w czasie, lecz w przekonaniu autorki bardziej doniosłymi. Można wręcz odnieść wrażenie, że w prowadzonych analizach celowo wycisza ona wszystkie symptomy XX-wiecznego „zgiełku” i koncentruje się przede wszystkim na wydobyciu ich powinowactw z filozofią minionych tysiącleci, a zwłaszcza z tą jej gałęzią, która była skłonna postrzegać rzeczywistość jako tajemniczą zagadkę do rozwiązania.

Dzięeki takiemu założeniu Misiak udało się wysunąć na pierwszy plan jedną z najbardziej charakterystycznych cech twórczości autora Aktu urodzenia: „Zagadka i labirynt, pojawiające się nieregularnie, lecz niejawnie w utworach Krynickiego, przypominają o pierwotnej funkcji poezji, która kondensuje wiedzę

8 G. Colli Narodziny filozofii, przeł. S. Kasprzysiak, Oficyna Literacka, Kraków 1994, s. 32-43, 52-60. 
o rzeczach teraźniejszych, przeszłych i wyłaniających się z przyszłości. Labirynt przywoływany w różnych ujęciach wydaje się poetycką pojemną figurą, a zarazem metodą pisania m.in. o traumatycznym poczuciu obcości w świecie, nieciągłej tożsamości podmiotu czy też o bezustannym przemieszczaniu się bohatera wierszy w przestrzeni między bytem a niebytem" (s. 14). Warto zwrócić uwagę na dokonujące się tutaj połączenie dwóch perspektyw; z jednej strony mowa tu o nawiązującej do czasów antycznych idei „pierwotnej funkcji poezji”, z drugiej natomiast o wiązce doświadczeń, jakie w najbardziej intensywny (a niekiedy również tragiczny) sposób wybrzmiały na gruncie literatury nowoczesnej, która usilnie poszukiwała języka pozwalającego na wyartykułowanie doświadczenia alienacji oraz dezintegracji ,ja”. Doznania te przeniknęły do sztuki wraz z pojawieniem się procesów modernizacyjnych, jakie nie uszły uwadze XX-wiecznych artystów, którzy szukali zupełnie nowej siatki pojęć dla wykształcającej się na ich oczach rzeczywistości. Tak było choćby z dochodzącym do głosu we wszystkich kanonicznych dziełach modernizmu problemem „nieciąłej tożsamości”, który pojawił się jako rezultat wielu równoległych obserwacji i odkryć z pogranicza nauki, filozofii i sztuki. Doprowadziły one do wytworzenia wielu języków artystycznych, za pomocą których artyści usiłowali wyartykułować to, co w ich mniemaniu było niepowtarzalną cechą epoki, w jakiej przyszło im żyć. Poezja Krynickiego była w znacznej mierze kontynuacją takich prób, ponieważ w miarę konsekwentnie testowała nowe sposoby lirycznej ekspresji, konstruowane na podstawie modeli wypracowanych na gruncie poezji nowoczesnej.

W Początku zagadki proces ten został opisany przez odwołanie do koncepcji zapożyczonej z książki Helen Vendler The Breaking of Style: Hopkins, Heaney, Graham ${ }^{9}$. Brytyjska badaczka, rozpatrując stylistyczną ewolucję twórczości trzech wymienionych w podtytule autorów, określiła "przełamywanie stylu" jako mimowolną i często niezależną od świadomości nagłą zmianę, w trakcie której „poczucie nowego sensu w nieoczekiwany sposób nawiedza poetę, sprawiając, że dotychczasowa forma literacka zaczyna wydawać mu się niewystarczająca bądź nawet odpychająca"10. Ponieważ w jej założeniu ma być to swoisty akt przemocy, jakiego autor dokonuje na swoim dotychczasowym „ja”, posłużyła się w swoich rozważaniach metaforą porzucenia jednego stylistycznego „ciała” (body) na rzecz nowego, bardziej adekwatnego do nowego obszaru poetyckich poszukiwań.

9 H. Vendler The Breaking of Style: Hopkins, Heaney, Graham - Harvard University Press, London 1995. 
Książka Misiak przedstawia trajektorię rozwoju poezji Krynickiego jako dramatyczny w swojej naturze proces dostosowania nowej formy wyrazu do zmieniających się przeświadczeń światopoglądowych. W takim właśnie duchu autorka pisze o interesujących ją przemianach: „przypuszczam, że nieregularne, precyzyjnie zorganizowane na poziomie brzmieniowym, leksykalnym semantycznym, składniowym wiersze Krynickiego odtwarzają zmienność świata" (s. 137). Hipoteza taka, dość bliska tej części poetów nowoczesnych, którzy przeprowadzali paralelę między spójnością rzeczywistości i formy literackiej, kładzie nacisk na moment zderzenia się wrażliwości artystycznej z rzeczywistością; podczas gdy we wczesnej twórczości autora Aktu urodzenia długie wersy miały był ekwiwalentem płynącego z tej kolizji lęku, to na kolejnym etapie na plan pierwszy wysuwała się strategia inna, polegająca na skracaniu wierszy oraz kondensowaniu ich treści. W Początku zagadki dynamika taka została opisana na podstawie bardzo uważnej i erudycyjnej analizy poszczególnych utworów, którym patronuje przekonanie, że nadrzędną cechą twórczości Krynickiego jest „bycie w drodze, niezadomowienie się w języku, nietrwały status zmieniających się wierszy, meandryczne zwroty między bytem/niebytem, milczenie skrywające jakieś sekrety" (s.139).

Konceptualizacja taka z jednej strony wpisuje się w dotychczasowe historycznoliterackie rozpoznania, z drugiej natomiast przesuwa horyzont interpretacji w zupełnie inną stronę. Ewolucja poezji Krynickiego jest w znacznej mierze tożsama z dynamiką poszukiwań innych rodzimych autorów, którzy zaczynali od inspiracji różnymi stylami awangardowymi, a następnie zarzucali je na rzecz odmiennych poetyk, którym patronowały np. dyskurs niewyrażalności lub też ciążenie w stronę różnych form z pogranicza milczenia i metafizyki. Wystarczy wspomnieć tutaj choćby o wyróżnionych przez Ryszarda Nycza czterech poetykach twórczości Czesława Miłosza"11, jak i o podlegającej ciągłym przemianom poezji Tadeusza Różewicza, Juliana Przybosia, Zbigniewa Herberta, poetów Nowej Fali i wielu innych autorów, których poszukiwania na różny sposób sprzęgnięte były z przygodą nowoczesności. Z drugiej strony jednak "sekrety”, o jakich wspomina Misiak w przytoczonym powyżej fragmencie, nabierają w sformułowanej przez nią propozycji interpretacyjnej szczególnego znaczenia. Nie tyle bowiem odsłaniają pesymistyczną wiedzę o kondycji jednostki w „czasie marnym”, co raczej stają się sygnałami istnienia głębszej tajemnicy, której zresztą na różny sposób niekiedy poszukiwali także niektórzy spośród wspomnianych przed chwilą autorów.

11 R. Nycz Miłosz wśród prądów epoki: cztery poetyki, "Teksty Drugie” 2001 nr 3/4. 
Interpretowane w takim kontekście motywy podróży i onirycznej wędrówki, stanowiące jedne z najważniejszych wątków w poezji Krynickiego, urastają do rangi wyprawy, której celem jest nie tyle pogodzenie różnych elementów wchodzących w skład „paradoksalnej całościowości” (M. Stala) ${ }^{12}$ lub spójne opisanie Całości (A. Świeściak) ${ }^{13}$, co raczej dotarcie do Pełni.

W takiej perspektywie błądzenie w labiryncie i rozwikływanie zagadek nabiera szczególnego znaczenia. Jak pisze Misiak, „zasadniczym impulsem w poezji Ryszarda Krynickiego jest przedfilozoficzne dążenie do badania rzeczy i zjawisk, które leżą poza granicami empirii, między magnetycznymi punktami bytu/niebytu. Konfrontacja z bezmiarem i chęć zrozumienia ciszy eteru jest próbą odsłonięcia widoku „na blask tam na górze” (s. 240). Imperatyw ten wyznacza nadrzędny porządek całej twórczości poety, który podejmował konsekwentne próby wyartykułowania tych skomplikowanych i niełatwych do zamknięcia w słowa założeń. Dostosowanie do nich warsztatu interpretacyjnego było zadaniem niełatwym, lecz w Początku zagadki udało się je zrealizować w sposób bardzo przekonujący, w czym duża zasługa rozległej erudycji autorki, przywołującej rozległe odniesienia filozoficzne, estetyczne i literackie, które współgrają z jej odczytaniem poezji Krynickiego. Rzecz jasna, oscylowanie między biegunami tak wielkich tematów prowadzi do nieuchronnej selekcji przywoływanych kontekstów, w książce Misiak na plan pierwszy zostały wysunięte te antyczne oraz wysokoartystyczne, mniej natomiast tutaj tych socjologicznych i kulturowych, poświadczających zakorzenienie poezji Krynickiego w „tu i teraz”. Dobrym przykładem rezultatu przyjęcia takiej perspektywy analitycznej są partie poświęcone wierszowi Bytem tutaj, które z jednej strony precyzyjnie opisują interesujące autorkę zagadnienia egzystencjalne i ontologiczne, z drugiej natomiast mniejszą uwagę przywiązują do zarysowującej się wyraźnie w tym tekście perspektywy społeczno-ekonomicznej (bieda i bezdomność w sercu cywilizacji) oraz popkulturowej (sygnalizowanej przez graffiti „Killroy was here”).

Niewątpliwym atutem książki jest często realizowania przez Misiak strategia interpretacyjna, jaka opiera się na uważnym badaniu kolejnych wersji tych samych utworów, które Krynicki poddawał wielokrotnej redakcji, polegającej na stopniowym redukowaniu ich treści, mającej na celu zarówno kondensację przekazu,jak i intensyfikację wpisanych w tekst wieloznaczności

12 M. Stala Purgatorium Na marginesie „Niepodległych nicości” w: tegoż Chwile pewności. 20 szkiców o poezji i krytyce, Znak, Kraków 1991.

13 A. Świeściak Przemiany poetyki Ryszarda Krynickiego, s. 7 
oraz niedopowiedzeń. Jest to nie tylko „przełamywanie stylu”, lecz również modelowanie wierszy w taki sposób, aby na pierwszy plan wysunąć refleksję metafizyczną, która podąża zresztą trudnym do przewidzenia szlakiem, co wedle autorki Początku zagadki spowodowane jest tym, że „twórczość Krynickiego jest zmienna, lecz konsekwentna, niejednorodna, gdyż wypełniają ją sprzeczne głosy, labiryntowa, ponieważ niełatwo wyznaczyć jej trasę, a nie zbliża się do żadnego końca" (s. 244).Z drugiej jednak strony to właśnie zwrot w stronę transcendencji, idący w parze z dążeniem do aforystycznej zwięzłości, doprowadził do pojawienia się w tejże twórczości haiku o wyraźnie nachylonej w stronę metafizyczną problematyce ${ }^{14}$. Obecność takiej formy poetyckiej Misiak jest skłonna uznawać za sygnał, że przed twórczością Krynickiego otwiera się nowy etap, zapowiadający możliwość wyjścia z labiryntu, skąd może wyprowadzić ją nie tylko mądrość filozofii przedplatońskiej, lecz również posiwiały duch europejskiego modernizmu ${ }^{15}$.

\section{Abstract}

\section{Aleksander Wójtowicz}

UMCS (LUBLIN)

Krynicki, Labyrinth, Mystery

Review: I. Misiak Początek zagadki: O labiryntowej twórczości Ryszarda Krynickiego [The Beginning of the Riddle: The Labyrinthine Work of Ryszard Krynicki], Stowarzyszenie Pro Cultura Litteraria Instytut Badań Literackich PAN, Warsaw 2015.

\section{Keywords}

Ryszard Krynicki, contemporary poetry, pre-Platonic philosophy, labyrinth in literature, riddle in literature

Zob. A. Świeściak Przemiany poetyki Ryszarda Krynickiego, s. 163-179 (rozdział W stronę buddyzmuzen)

15 Jak przekonuje Beata Śniecikowska, „estetyczno-filozoficzna atrakcyjność japońskich miniatur silnie splata się z formacją szeroko rozumianego modernizmu". Zob. Haiku po polsku. Genologia w perspektywie transkulturowej, Wydawnictwo Naukowe UMK, Toruń 2016, s. 644. 